\title{
Surgical Results of the Intraoral Removal for Plunging Ranula
}

\author{
Ki Hwan Hong, Yun Su Yang, Hee Taik Park, Byung Eun Hwang, \\ Kyung Suk Lee, Sang Ho Lim and Soon Ho Yu \\ Department of Otolaryngology-Head and Neck Surgery, Chonbuk National University Medical School, Jeonju, Korea
}

\section{구강을 통한 몰입형 하마종의 수술적 치료}

홍기환 · 양윤수 · 박희택 · 황병언 · 이경석 · 임상호 · 유순호

전북대학교 의학전문대학원 이비인후과학교실

Received May 31, 2010

Revised October 4, 2010

Accepted October 4, 2010

Address for correspondence

Ki Hwan Hong, MD

Department of Otolaryngology-

Head and Neck Surgery,

Chonbuk National University

Medical School,

Geumam 2-dong, Deokjin-gu,

Jeonju 561-712, Korea

Tel $+82-63-250-1990$

Fax $+82-63-250-1986$

E-mail khhong@chonbuk.ac.kr
Background and Objectives Although sclerotherapy has been recently applied for plunging ranula, surgical approaches such as marsupialization have been the primary mode of treatment. Marsupialization may be done through simple excision via transcervical approach or via combined approach, intraorally and trabscervically. This study examined the effectiveness of intraoral excision for the treatment of plunging ranula.

Subjects and Method This prospective clinical study was comprised of 15 patients who were treated for plunging ranula through intraoral excision of the raluna and sublingual gland.

Results All of the 15 patients showed a complete removal of sublingual gland. The cystic wall of ranula could be dissected for only three patients (20\%) and for twelve patients $(80 \%)$, it could not be dissected intraorally. Rupture of ranula developed in all patients (100\%) during intraoral dissection. Recurrence did not occurr at all during a median follow-up period of 14 months (range, 7-35 month) after the intraoral excision. There were no side effects and external scarring.

Conclusion The intraoral approach for removal of the plunging ranula is highly effective as a primary treatment modality of plunging ranula.

Korean J Otorhinolaryngol-Head Neck Surg 2010;53:702-5

Key Words Ranula $\cdot$ Excision.

\section{서 론}

하마종은 구강저의 설하선 혹은 혀의 기저부의 소타액선 에 발생하는 저류성 낭종으로 구강저에 낭종성 종물로 나 타나는 단순 하마종이 대부분을 차지하나 악설골근(mylohyoid muscle) 밑으로 침범되어 악하부 종물로 나타나는 몰입형 하마종(plunging ranula)이 있다. 몰입형 하마종 은 설하선에서 생긴 피막 없는 위낭종(pseudocyst)이 설하 공간을 지나 악하공간까지 침범된 경우로서 설하선에서 분 비된 타액이 관외유출을 통해 주변의 공간에 정체되어 생기
는 것이다. ${ }^{2}$ 하마종에 대한 수술적 처치로는 단순 절제술, 조대술(marsupilization) 그리고 및 낭종 및 설하선제거 등의 수술적 처치와 OK-432(picibanil)를 이용한 경화요 법 등이 보고되고 있다. ${ }^{3-6)}$

특히 몰입형 하마종에 대한 치료는 하마종을 유발하는 설하선의 제거가 가장 적절한 치료로써 이제까지 시행되어 온 경부 절개를 통한 설하선의 절제는 악하선 제거 후 시행 되며 또한 불완전하게 설하선을 제거할 가능성이 있다. ${ }^{7)}$ 또 한 구강을 통한 설하선 제거와 경부절개를 통한 낭종 제거 는 설하선을 완전제거할 수 있다는 장점이 있으나 경부 절 
개로 인한 술흔 등의 미용상 문제가 제기되어 왔다. 최근에 는 경부절개 없는 구강을 통한 설하선 제거로 몰입성 하마 종을 치료한 보고가 있었던 바 ${ }^{8-12)}$ 본 저자들은 구강을 통 한 설하선 제거와 동시에 낭종 제거 혹은 배액술 등으로 몰 입성 하마종을 치료하여 문헌적 고찰과 함께 보고하는 바 이다.

\section{대상 및 방법}

\section{대 상}

대상은 본원 이비인후과학교실에서 2006년 9월부터 몰입 성 하마종으로 진단되어 수술을 받은 환자 15예를 대상으로 후향적으로 의무 기록을 나이, 성별, 병원 내원 당시의 주 증상, 과거의 수술력 등을 분석하였다. 몰입형 하마종에 대 한 분류는 이학적 검사 및 컴퓨터단층촬영을 통해 악하부 만 종물이 나타난 악하형, 설하부 및 악하부에 동시에 종물
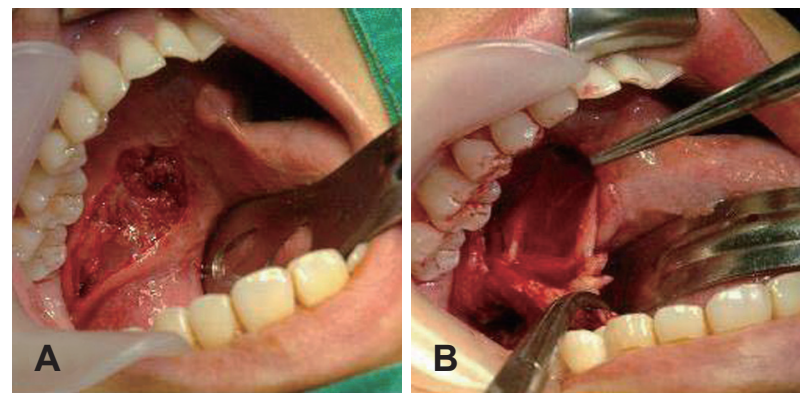

Fig. 1. Intraoral incision (A). Complete removal of the sublingual gland with preserving lingual nerve and Wharton's duct (B).
을 보인 혼합형으로 구분하였다.

\section{수술방법}

모든 환자에서 전신마취를 통한 수술이 진행되었고, 기관 삽관은 비강을 통해 시행하였으며, 구강을 충분히 세척한 후 치아견인기를 이용하여 구강을 노출시켰다. 본 수술을 위하 여 사용한 보조적 수술도구는 편도지혈자, 구강노출을 위한 치아견인기 및 좋은 시야를 위한 화이버경 견인기 등이었다. 먼저 혀를 정상측으로 견인하여 병변측 구강저를 충분히 노 출시킨 후 하악 최후방 내측으로 부터 혀의 접촉선과 중간 부 구강점막을 향하여 전방으로 악하선도관 입구부까지 구 강저를 절개하였다. 점막하 설하선을 모두 박리한 후 악하 선 도관을 확인한 다음 도관을 따라 후방으로 박리하면서 설신경을 확인하고 도관과 교차하는 부위에서 도관의 상방 으로 주의깊게 박리하였다. 설신경 및 도관 상방에 있는 설 하선을 주위 조직으로부터 완전히 박리하여 상방으로 끌어 올리면서 적출하였다(Fig. 1). 수술 조수로 하여금 하악부를 상방으로 압박하면 하마종이 상방으로 밀려 올라와 상층부 가 쉽게 노출된다. 이 상태에서 낭종을 둘러싸고 있는 주위 조직 및 악설골근을 박리하면 낭종이 쉽게 노출된다. 설하 선과 낭종이 연결된 경우는 설하선과 같이 낭종을 완전제 거 하도록 노력하였지만 동시제거가 용이하지 않은 경우 설 하선 제거 후 낭종막을 따라 주의깊게 박리하면서 구강을 통해 완전히 적출 되도록 하였으나 낭종막의 완전제거 여부 는 확인할 수 없었다(Fig. 2). 낭종막의 완전 적출이 안된 경 우 낭종액을 완전 배액 후 $76 \%$ 알콜 스폰지액으로 문지르
Fig. 2. Exposed sublingual and submandibular cyst (A). Well dissected sublingual cyst (B). Dissected and extirpated submandibular cyst (C). Specimen of sublingual gland and cyst (D).
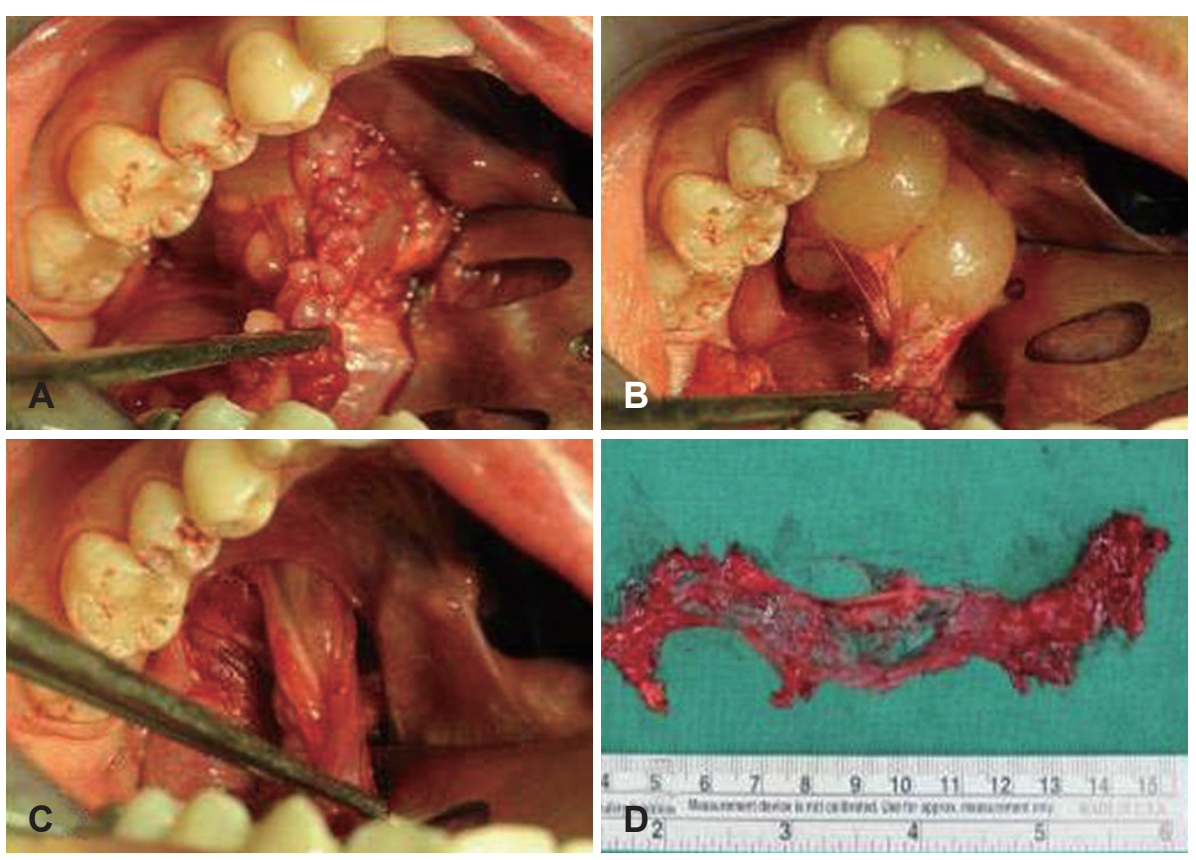
면서 2 3분간 알콜액에 적시어 낭종막이 쉽게 경화되도록 유도하였다. 술 후 회복실에서 구강내 절개부위를 거즈를 이용하여 환자 스스로 압박하게 하였고, 악하선부위는 압박 드레싱을 하였다. 구강내 거즈와 압박은 수술 후 다음날에 제거하였다.

\section{결 과}

연구대상군은 6 명의 남자와 9 명의 여자로 구성되었고 내 원 당시의 나이는 9 세부터 43 세까지로 평균 24 세였다. 주 증상은 악하부 종물로 11 명에서 관찰되었고 구강저 및 악하 부에 동시에 종물을 보인 혼합형이 4명이었다. 과거력상 3 명에서 정확한 진단이 내려지기 전에 하마종 조대술 혹은 설하선 불완전제거술을 시행받은 적이 있었고 4명에서 과거 에 $\mathrm{OK}-432$ 를 이용한 경화요법의 과거력이 있었다. 모든 환 자에서 구강을 통해 설하선 제거 및 악하선관 보존이 가능 하였으며 특히 구강을 통한 반복시술의 기왕력이 있었던 3 명 중 1 명의 환자에서 주위조직에 유착이 있는 악하선관을 절재 후 도관 전이술을 시행하였다. 전체 환자 중 3 명의 환 자에서 설하선 제거 후 낭종의 완전 적출이 가능하였으나 12 명의 환자에서 구강을 통한 낭종의 완전적출은 불가능하여 알콜 스폰지를 이용하여 낭종막이 경화되도록 유도하였다. 과거력상 경화료법 후 재발하였던 4 명의 환자에서 수술 중 특이한 소견은 관찰되지 않았다. 수술 후 출혈 혹은 설신경 및 설하신경의 마비는 없었으며, 일시적으로 악하부 동통 및 약 2 주간의 악하부의 부종증이 발생하였으나 모든 환자에서 수술 후 시간이 지남에 따라 악하부의 부종과 단단한 정도 는 호전되었다. 전체 평균 추적기간은 14 개월(7 35개월)이 었으며 특히 알코홀 경화요법을 시행하였던 환자의 평균 추 적기간은 11 개월로 현재까지 재발한 경우는 없었다. 모든 환 자에서 술 후 조직학적 검사를 시행하였던 바 낭종의 벽이 느슨한, 혈관분포성의 결막조직이 관찰되었고 상피 내층의 결여가 관찰되었다.

\section{고 찰}

하마종은 설하선이나 소타액선관의 손상으로 인한 관의 폐쇄에 의해 발생하는 가성 낭종으로 위치에 따라 설하부 (sublingual type), 설하-악하부(sublingual-submandibular type), 악하부(submandibular type)로 구분되며 설하부는 단순 하마종으로, 설하-악하부와 악하부는 몰입 형 하마종으로 분류된다. ${ }^{5,6)}$ 단순하마종은 구강저에 국한되 어 대부분 설하선의 점액 저류낭으로 나타나며 몰입형 하마
종은 드물지만 설하공간을 지나서 악하공간에 나타는 낭종 으로 대부분 구강 내 특이 소견 없이 나타난다. 하마종이 몰 입형 하마종으로 확장되는 경로는 악설골근과 설골설근 사 이의 악하선의 심엽을 통한 경로와 악설골근 자체의 선천적 결손에 의한 경로 등으로 설명된다. ${ }^{8)}$ 몰입형 하마종은 구강 내 부종으로 먼저 나타나고(45\%) 구강내 병변과 동시에 (34\%) 혹은 경부 종물로(21\%) 나타난다. ${ }^{2}$ 설하선에서 생긴 낭종이 악설골근의 결함을 통해 돌출되어 구강내에 이상이 없이 경부 종물로 나타날 수 있으나 ${ }^{6)}$ 대부분 악하공간에 위 치하여 턱끝밑 공간이나 양측 경부 혹은 후인두나 쇄골 위 까지 침범하기도 한다. 림프절병증, 농양, 설관낭종, 유피낭 종, 후두낭종 및 갑상선 낭종 등으로 오인되기도 하지만 컴 퓨터단층촬영상 균질하고 낮은 조영증강을 보이는 낭성 종 물의 인접한 설하선으로부터 악하선강 또는 부인강으로 확 장되는 것을 관찰할 수 있다. ${ }^{8)}$

일반적인 하마종에 대한 치료는 비수술적 방법과 수술적 인 방법이 보고되었다. ${ }^{8)}$ 비수술적 치료방법으로는 $\mathrm{OK}-432$ (picibanil)를 이용한 경화요법이 대표적이다. ${ }^{3-6)}$ Picibanil 은 항암제로 사용되어 왔으며 암환자의 복수와 흉수의 양 을 줄이는 데 효과가 있고 ${ }^{9}$ 소아 림프관종과 재발한 림프관 종의 치료에 탁월한 효과가 있다고 보고되었다. ${ }^{4)} \mathrm{OK}-432$ 를 이용한 경화 요법은 외래에서 쉽게 시술이 가능하고 치료 성 적이 우수하며 심한 부작용이 없어 하마종의 일차 치료에 효과적일 수 있다. ${ }^{5,8)}$ 그러나 본 연구에서는 경화요법에도 불 구하고 약 4 명의 환자에서 경화요법 후 재발소견을 보여 완 전한 시술로는 의문점이 남아있다. 그러므로 수술적 방법이 주로 시도되나 완전제거가 쉽지 않고, 낭종이 파열될 우려가 높으며 병변의 불완전한 제거와 높은 재발률 그리고 악하선 관이나 설신경 등 주위 구조물들이 손상받을 위험성 등 여 러 문제점이 있다. 수술적 방법으로는 낭종의 단순 절제, 조 대술, 설하선의 제거 등 고식적인 수술 방법들이 있지만 낭 종의 단순 절제와 조대술은 높은 재발률을 보여 거의 시행 되지 않으며 설하선 제거를 동반한 하마종 제거가 안전한 수술로 시행되어졌다. 몰입성 하마종에 대한 수술적 접근으 로는 과거에는 낭종의 완전 절제를 위해 구강 접근법보다는 경부 접근법을 사용하기도 하였다. 그러나 장기 추적 관찰 결과 설하선을 제거하지 않은 경우 많은 재발률을 보였으며 설하선을 동시에 제거한 경우 재발률이 현저히 낮았다. 그 러나 경부를 통한 낭종 제거는 경부 술흔, 신경 손상, 하악 선관 손상과 협착 및 타액 유출 등의 여러 후유증을 유발 할 수 있다. ${ }^{7)}$

최근 들어 하마종을 생성하는 분비조직을 제거하는 것이 가장 합리적인 치료로 간주되어지고 있다.8) 경부에 나타나 
는 낭종은 비록 완전 절제를 시행하지 않아도 몰입성 하마 종의 낭종은 상피성의 내층이 결여된 가성낭종이므로 낭종 의 벽은 관외유출된 점액에 대한 반응성으로 생긴 얇은 섬 유성 조직으로 이루어졌기 때문이다. ${ }^{12-12)}$ 구강을 통한 설하 선의 제거는 경부를 통한 낭종제거에 비해 좁은 수술시야 및 접근의 어려움 등이 있을 수 있지만 설신경의 완전한 확 인과 보존이 가능하여 설신경 손상이 없으며 경부절개가 없 기 때문에 안면신경 마비 등은 우려하지 않아도 된다. 대부 분 경부 낭종은 구강을 통해 완전히 적출할 수 없지만 완전 제거가 안되어도 낭종막 내측의 경화를 촉진시키면 낭종의 재발이 없었다. 수술 중 악하선관이 구강내의 낭종 및 염증 에 의해 손상된 경우는 설하선의 제거와 악하선 도관의 전 이술 즉 악하선 도관을 인근 점막에 고정해주는 시술을 시 행하여 도관의 협착 및 타액의 흐름에 지장이 없도록 유도 하였다. 수술 후 후유증으로 하마종의 재발은 없었으며 설 신경 손상 등의 신경마비는 없었고 설하선을 완전히 제거하 여 재발성의 점액낭종은 없었다.

결론적으로 저자들은 몰입성 하마종에 대하여 모든 환자 에서 구강을 통하여 설하선을 제거하였고 설하선 제거 후 악하부를 1 2일간 압박하였으며 모든 환자에서 술 후 출혈 은 관찰되지 않았다. 일시적인 통증 및 부종이 관찰되었으 나 1 주일 후 소실되었으며 추적 관찰한 결과 특별한 후유증 및 재발은 없었기에 구강을 통한 하마종 및 설하선 제거를 통해 몰입성 하마종을 재발없이 치료가 가능하다고 보고하
는 바이다.

\section{REFERENCES}

1) De Visscher JG, van der Wal KG, de Vogel PL. The plunging ranula. Pathogenesis, diagnosis and management. J Craniomaxillofac Surg 1989;17(4):182-5.

2) Davison MJ, Morton RP, Mclvor NP. Plunging ranula: clinical observations. Head Neck 1998;20(1):63-8.

3) Roh JL. Primary treatment of ranula with intracystic injection of OK-432. Laryngoscope 2006;116(2):169-72.

4) Fukase $S$, Ohta $N$, Inamura $K$, Aoyagi $M$. Treatment of ranula with intracystic injection of the streptococcal preparation OK-432. Ann Otol Rhinol Laryngol 2003;112(3):214-20.

5) Woo JS, Hwang SJ, Lee HM. Recurrent plunging ranula threated with OK-432. Eur Arch Otorhinolaryngol 2003;260:226-8.

6) Kim MG, Cho EY, Song JW. The effect of the sclerotherapy of plunging ranula with the use of picibanil. Korean J Otolaryngol-Head Neck Surg 2004;47(12):1278-81.

7) Ichimura K, Otha Y, Tayama N. Surgical management of the plunging ranula: a review of seven cases. J Laryngol Otol 1996;110(6): 554-6.

8) Yoo BY, Yoo JK, Kim DK, Lee EJ, Park JS. Intraoral approach in plunging ranula. Korean J Otolaryngol-Head Neck Surg 2005;48(4): 516-9.

9) Kim HS, Roh JL. Sclerotherapy of ranula with intracystic injection of OK-432. Korean J Otolaryngol-Head Neck Surg 2006;49(10): 1003-7.

10) Lee HM, Lee HJ, Cho JG, Song JS, Lee SH, Woo JS, et al. Clinical analysis of the 22 cases of plunging ranula. Korean J OtolaryngolHead Neck Surg 2003;46(9):764-8.

11) Zhao YF, Jia Y, Chen XM, Zhang WF. Clinical review of 580 ranulas. Oral Surg Oral Med Oral Pathol Oral Radiol Endod 2004;98(3): 281-7.

12) Chidzonga MM, Mahomva L. Ranula: experience with 83 cases in Zimbabwe. J Oral Maxillofac Surg 2007;65(1):79-82. 